\title{
Isolation and molecular characterization of Leishmania infantum in urine from patients with visceral leishmaniasis in Brazil
}

Manoel Sebastião da Costa Lima Junior ${ }^{1 *}$, Andressa Cristina Lopes Hartkopf ${ }^{2}$, Rosianne A. de Souza Tsujisaki ${ }^{2}$, Elisa Teruya Oshiro ${ }^{3}$, Julie Teresa Shapiro ${ }^{4}$ Maria de Fatima Cepa Matos $^{2}$, Maria Elizabeth Cavalheiros Dorval ${ }^{5}$

${ }^{1}$ Laboratory of Immunopathology and Molecular Biology, FIOCRUZ - Instituto Aggeu Magalhães, Recife, PE, Brazil.

${ }^{2}$ Laboratory of Molecular Biology and Cell Culture, Universidade Federal de Mato Grosso do Sul, Av. Senador Filinto Müller, s/n., Campo Grande, MS, Brazil.

${ }^{3}$ Center for Biological and Health Sciences, Universidade Federal de Mato Grosso do Sul, Campo Grande, MS, Brazil.

${ }^{4}$ School of Natural Resources and the Environment and Department of Wildlife Ecology and Conservation, University of Florida, Gainesville, FL, USA, 32601

${ }^{5}$ Graduate Program in Infectious and Parasitic Diseases, Universidade Federal de Mato Grosso do Sul, Faculdade de Medicina, Unidade IX, Caixa postal 549, Campo Grande, MS 79070-900, Brazil.

"Correspondence should be addressed to: Manoel Sebastião da Costa Lima Junior; manoel.lima@cpqam.fiocruz.br 


\section{ABSTRACT}

Leishmania infantum is a protozoan that causes visceral leishmaniasis, a potentially deadly neglected tropical disease. The gold standard for diagnosis has traditionally been detection of amastigotes in bone marrow or spleen aspirates, but this is an invasive procedure that carries the risk of serious complications. Newer PCR techniques are opening new avenues and tissues for testing. Therefore, we tested if amastigotes and DNA from $L$. infantum could be detected in patient urine. We detected $L$. infantum DNA in six out of 30 urine samples from patients with visceral leishmaniasis and the promastigotes were isolated in culture from the urine of one patient. These results suggest the feasibility of using urine samples to diagnose visceral leishmaniasis, especially in acute cases or renal infection, providing a valuable tool for doctors and clinicians to use for screening and diagnosis of leishmaniasis in patients.

Keywords: Urine, Leishmania, Diagnosis, PCR, Zoonosis 


\section{Introduction}

The protozoan Leishmania infantum is the causative agent of visceral leishmaniasis (VL) (Desjeux, 1992), a neglected tropical disease that attacks the internal organs is often fatal if not properly treated (Desjeux, 1996). L. infantum is endemic in South America (Desjeux, 1992) and is a particular problem in Brazil, which accounts for the majority of VL cases reported in Latin America (Hotez et al., 2008).

Traditionally, infection with $L$. infantum was diagnosed via identification of amastigotes in the spleen or bone marrow (Guerin et al., 2002; Zijlstra et al., 1992). Serological tests for antibodies or antigens have also been used (Chappuis et al., 2007). Both of these methods have some disadvantages. Obtaining spleen or bone marrow aspirates carries the risk of serious complications and requires a high level of expertise (Chappuis et al., 2007; Guerin et al., 2002). Serology, though a valuable tool, can be unreliable due to the possibility of cross-reaction with other parasites (Caballero et al., 2007). It also cannot detect relapses since patients' serology test may remain positive after treatment (Chappuis et al., 2007).

More recently, techniques based on polymerase chain reaction (PCR), with high sensitivity and specificity, have been developed for VL diagnosis. PCR-based detection can be applied to many different types of biological samples, such as blood, bone marrow, and serum (Fraga et al., 2010; Motazedian et al., 2008). These techniques also allow different Leishmania species to be identified, which is not possible with traditional microscopy (Lima Junior et al., 2009). The use of PCR-based techniques has also expanded the types of samples from which L. infantum can be detected, including urine (Lachaud et al., 2001). This has successfully detected the DNA of Leishmania parasites in both humans and canines (Fisa et al., 2008; Mebrahtu et al., 1993; Silva et al., 2014; Solano-Gallego et al., 2007)

Here we report the detection of $L$. infantum in human urine samples. VL is a potentially fatal disease (Desjeux, 1996). There is an urgent need for a fast and reliable diagnostic tools (Fisa et al., 2008). The symptoms of leishmaniasis are often similar to many other tropical diseases; an early diagnosis, which leads to patients getting appropriate treatment faster, is one of the most important factor for preventing morbidity (Chappuis et al., 2007; Oliveira et al., 2010). The application of PCR detection of Leishmania to urine samples would offer many advantages by for patients by providing a 
reliable, painless, and less invasive approach for the collection of biological material that could lead to timely diagnosis and earlier treatment.

\section{Materials and methods}

\subsection{Patients and study site}

This study was conducted at the teaching hospital of the Universidade Federal de Mato Grosso do Sul (UFMS) in Campo Grande, Mato Grosso do Sul state, Midwest Brazil.

Thirty patients with VL were selected, based on clinical criteria and laboratory confirmation by direct observation of parasitic forms in bone marrow aspirate and/or rapid test (Kalazar Detect, Inbios International, Seattle, WA, USA). In addition, fifty controls from healthy individuals, serologically and molecularly negative for Leishmania sp. on the indirect fluorescent antibody test, were also included in analysis. Each individual provided a $50 \mathrm{~mL}$ sample of urine.

The study was approved by the UFMS Research Ethics Committee (permit 87399, CAAE 05063012.3.0000.0021).

\subsection{Collection and processing of biological samples}

Samples were collected from August 2012 to October 2013. Urine samples were collected in the morning, before patients received treatment. Samples were stored at $20^{\circ} \mathrm{C}$. A $5 \mathrm{~mL}$ aliquot was centrifuged at $4000 \mathrm{rpm}$ for $10 \mathrm{~min}$ and the sediment inoculated in duplicate into the liquid phase of Novy-MacNeal-Nicole medium and Schneider's medium supplemented with $10 \%$ fetal bovine serum. The resulting culture was examined weekly for 60 days. The remaining urine was centrifuged at $14000 \mathrm{rpm}$ for $5 \mathrm{~min}$ and the sediment stored for DNA extraction.

\subsection{DNA extraction from cultures}

The parasitic mass obtained from each culture was washed with PBS, and DNA was extracted using a QIAquick Gel Extraction kit (Qiagen) according to the manufacturer's instructions. An aliquot of reagent mixture devoid of DNA, in $5 \mu \mathrm{L}$ of water, served as the negative control.

\subsection{DNA extraction from urine}


A $6 \mathrm{~mL}$ volume of urine was centrifuged at $14000 \mathrm{rpm}$ for $5 \mathrm{~min}$ and the supernatant discarded. A $300 \mu \mathrm{L}$ volume of lysis buffer $(1 \mathrm{M} \mathrm{NaCl} ; 1 \mathrm{M}$ Tris- $\mathrm{HCl}$ at $\mathrm{pH}$ 8; $0.5 \mathrm{M}$ EDTA at $\mathrm{pH}$ 8.0) and $200 \mu \mathrm{L}$ of $10 \%$ SDS were added and the mixture was homogenized by vigorous vortexing, followed by addition of $20 \mu \mathrm{L}$ of proteinase $\mathrm{K}$ (20 $\mathrm{mg} / \mathrm{mL}$ ). The resultant mixture was then incubated at $65^{\circ} \mathrm{C}$ for $1 \mathrm{~h}$, followed by addition of $400 \mu \mathrm{L}$ of chloroform, vigorous stirring until complete homogenization, and subsequent centrifugation at $10000 \mathrm{rpm}$ for $10 \mathrm{~min}$. The aqueous phase was transferred to a clean tube for DNA precipitation with $100 \%$ ethanol. A $70 \%$ ethanol solution was added to the pellet and centrifuged at $10000 \mathrm{rpm}$ for $10 \mathrm{~min}$, after which the supernatant was discarded. This step was repeated twice. The dry pellet was resuspended in $50 \mu \mathrm{L}$ of ultrapure water, incubated at $4{ }^{\circ} \mathrm{C}$ overnight, and stored at $-20{ }^{\circ} \mathrm{C}$ until time of analysis (Maniatis et al., 1982).

\subsection{Analysis of DNA integrity}

$\beta$-Actin was employed as a marker, as described by Ferreira et al. (2010). The primers ACTIN-F (5'-CGGAACCGCTCATTGCC-3') and ACTIN-R (5'ACCCACACTGTGTGCCCATCTA-3') were employed (du Breuil et al., 1993; Tohgi et al., 1998). Cycling consisted of initial denaturation at $95{ }^{\circ} \mathrm{C}$ for $4 \mathrm{~min}$ followed by 35 cycles at $94{ }^{\circ} \mathrm{C}$ for $30 \mathrm{~s}$ for denaturation, $59^{\circ} \mathrm{C}$ for $30 \mathrm{~s}$ for annealing, $72{ }^{\circ} \mathrm{C}$ for $1 \mathrm{~min}$ for extension, and one final 5 min extension cycle at $72^{\circ} \mathrm{C}$.

\subsection{PCR-RFLP}

The positive samples were subjected to an additional PCR using oligonucleotides LITSR (5'-CTGGATCATTTTCCGAT-3') and L5.8S (5'-TGATACCACTTATCGCACTT-3') (El Tai et al., 2001). These primers amplify the Internal Transcribed Spacer 1 (ITS1) region, with an amplification product estimated at between 300 and $350 \mathrm{bp}$. The reactions were performed on a Bio-Rad T100 ThermalCycler apparatus at a final volume of $25 \mu \mathrm{L}$ containing $1 \mathrm{X}$ buffer (Invitrogen), $0.2 \mathrm{mM}$ dNTPs, $1.5 \mathrm{mM} \mathrm{MgCl}_{2}, 4 \%$ formamide, 0.4 pmol of each primer, Taq DNA polymerase at $10 \mathrm{U} / \mu \mathrm{L}$ (Phoneutria), $1 \mu \mathrm{L}$ of DNA at 30-200 $\mathrm{ng} / \mu \mathrm{L}$, and $17.25 \mu \mathrm{L}$ of water. Cycling began at $95^{\circ} \mathrm{C}$ for $3 \mathrm{~min}$, followed by 35 cycles each at $95{ }^{\circ} \mathrm{C}$ for $30 \mathrm{~s}, 55^{\circ} \mathrm{C}$ for $30 \mathrm{~s}$, and $72{ }^{\circ} \mathrm{C}$ for $1 \mathrm{~min}$, ending with a final 5 min extension at $72{ }^{\circ} \mathrm{C}$.

Leishmania braziliensis (MHOM/BR/75/M2903), L. infantum (MHOM/BR/74/PP75), and L. amazonensis (IFLA/BR/67/PH8) DNA samples obtained from cultures served as the positive controls for PCR. 
To characterize the Leishmania species involved, these PCR amplicons were subjected to restriction-fragment length polymorphism (RFLP) analysis using the restriction enzyme Hae III (Schönian et al., 2003). RFLP conditions: $25 \mu \mathrm{L}$ volume, $1 \mu \mathrm{L}$ of Hae III, 2 $\mu \mathrm{L}$ of $\mathrm{M} 10 \mathrm{x}$ buffer, $5 \mu \mathrm{L}$ of sterile water, and $17 \mu \mathrm{L}$ of amplicon, followed by incubation at $37{ }^{\circ} \mathrm{C}$ for $3 \mathrm{~h}$. The PCR-RFLP products were then analyzed by electrophoresis in highresolution agarose gel (Sigma-Aldrich, St. Louis, MO, USA) at $3 \%$ with $1 \mathrm{X}$ tris-borateEDTA buffer at $\mathrm{pH}$ 8.0. Electrophoresis was run at $100 \mathrm{~V}$ and $400 \mathrm{~mA}$ for $3 \mathrm{~h}$. The gels were visualized under UV after ethidium bromide staining $(0.5 \mu \mathrm{g} / \mathrm{mL})$.

\section{Results}

Of the patients investigated, $22(73.3 \%)$ were males and eight $(26.7 \%)$ females. Age ranged from two to 85 years. On admission, symptoms were consistent with VL, namely, hepatomegaly $(80 \%)$, splenomegaly $(80 \%)$, fever $(70 \%)$, weight loss $(60 \%)$, weakness $(60 \%)$, pallor $(60 \%)$, and cough $(40 \%)$.

On the 14th day of urine culture, growth of promastigotes was observed in a sample from a three-year-old boy who was diagnosed with VL on parasitological examination. The patient also presented a fever $\left(38.7^{\circ} \mathrm{C}\right)$, abdominal pain, vomiting, pallor, appetite loss, and hepatosplenomegal. The patient was initially treated with penicillin for three days and subsequently with ceftriaxone associated with oxacillin for 10 days. Glucantime, a VLspecific drug, was administered for 20 days in association with ceftriaxone and oxacillin.

No growth of parasitic forms was observed in 22 samples (73\%). Seven samples (23\%) were contaminated with other microorganisms.

Using PCR, Leishmania sp. DNA was detected in 11 urine samples (Figure 1) (37\%), five of which (17\%) were positive on PCR-ITS1 (Figure 2). However, the paucity of DNA content precluded specific characterization of all DNA samples.

Based on PCR-RFLP of both urine sediment and promastigote forms obtained from cultures, the infective agent in all samples was identified as Leishmania infantum. No Leishmania was detected by PCR in any of the negative controls. There was also no growth of promastigotes in culture from the negative controls.

\section{Discussion}

Effective control and treatment of $\mathrm{VL}$ depends on timely, accurate diagnosis (Oliveira et al., 2010). Diagnosis based on PCR detection in urine samples may represent a promising, non-invasive and painless alternative approach, especially compared to 
obtaining bone marrow and spleen samples from patients for detection of amastigotes (Chappuis et al., 2007; Zijlstra et al., 1992). Although only a portion (37\%) of patients tested positive, examining urine can provide an additional tool for doctors to quickly screen patients for VL and more rapidly diagnose at least a portion of them. In addition, PCR has high sensitivity and can show $100 \%$ specificity to Leishmania species (Andresen et al., 1997; Fisa et al., 2008; Motazedian et al., 2008; Solano-Gallego et al., 2007). Although the isolation of Leishmania (Leishmania) infantum from urine samples has previously been reported (Ferroglio et al., 2006; Motazedian et al., 2008), the present study is the first to identify viable amastigotes in urine from Brazilian patients.

Nevertheless, there are some challenges in the use of urine for diagnosing VL. The growth of amastigotes in culture was observed in only a single sample and difficulties in isolating the parasite from urine have been reported elsewhere (Mebrahtu et al., 1993). Low success rates can be due to technical difficulties during collection and preservation, as well as low numbers of parasites in the samples, the inability of Leishmania DNA to cross the renal barrier and contamination of urine with other microorganisms (Cruz et al., 2006).

Some of the negative PCR results could be explained by difficulties in DNA extraction and amplification (Andresen et al., 1997). Urine contains factors, such as urea and nitrites, which may have an inhibitory effect on DNA amplification (Khan et al., 1991). In addition, DNA can be degraded by endonucleases secreted by bacteria present in urine (Carder et al., 1999; Milde et al., 1999). Further testing of the best way to preserve and treat urine samples may increase the utility of this method. Treatment of samples to reduce inhibition, such as keeping samples at $-70^{\circ} \mathrm{C}$ or below (Madisen et al., 1987), precipitating suspended solids, using ethanol, and concentrating DNA could increase the success of Leishmania detection in urine samples, as well as modification of amplification techniques that can detect smaller fragments of more degraded DNA (Silva et al., 2014).

Despite these challenges, the detection of Leishmania parasites in urine may be especially useful for determining if the kidneys have been infected. Renal involvement has been frequently reported in patients with VL (Chaigne et al., 2004; Efstratiadis et al., 2006; Elshafie et al., 2006; Prasad et al., 1992; Romero Maroto et al., 1995; Salgado Filho et al., 2003). The presence of amastigotes or Leishmania particles in the kidneys may indicate the acute phase of the disease, renal lesions, or very high parasite loads (Caravaca et al., 1991; Fisa et al., 2008; Salgado Filho et al., 2003). 
The present results show that human urine can be used as a biological sample for identifying Leishmania species and provide a relatively painless, minimally invasive method for doctors to screen patients. Although further studies are needed to determine the best methods for culturing, extracting DNA, and amplifying this type of biological sample, it holds promise for providing a rapid diagnosis for patients, especially when the kidneys have been infected.

\section{Acknowledgments}

The authors wish to thank Fundect-MS (Brazil) for the support provided to the present study. J.T. Shapiro was supported by a National Science Foundation Graduate Research Fellowship (DGE-1315138) 


\section{References}

Andresen, K., Gasim, S., Elhassan, A.M., Khalil, E.A.G., Barker, D.C., Theander, T.G., Kharazmi, A., 1997. Diagnosis of visceral leishmaniasis by the polymerase chain reaction using blood, bone marrow and lymph node samples from patients from the Sudan. Trop. Med. Int. Heal. 2, 440-444. doi:10.1111/j.1365-3156.1997.tb00166.x

Caballero, Z.C., Sousa, O.E., Marques, W.P., Saez-Alquezar, A., Umezawa, E.S., 2007. Evaluation of serological tests to identify Trypanosoma cruzi infection in humans and determine cross-reactivity with Trypanosoma rangeli and Leishmania spp. Clin. Vaccine Immunol. 14, 1045-9. doi:10.1128/CVI.00127-07

Caravaca, F., Mu\&ntilde;oz, A., Pizarro, J.L., de Santamaria, J.S., Fernandez-Alonso, J., 1991. Acute Renal Failure in Visceral Leishmaniasis. Am. J. Nephrol. 11, 350-352. doi:10.1159/000168337

Carder, C., Robinson, A., Broughton, C., Stephenson, J., Ridgway, G., 1999. Evaluation of self-taken samples for the presence of genital Chlamydia trachomatis infection in women using the ligase chain reaction assay. INT J STD AIDS , 10776 - 779.

Chaigne, V., Knefati, Y., Lafarge, R., Bronner, J., Mc Gregor, B., Fouque, D., Sabatier, J.C., 2004. Leishmaniose viscérale autochtone avec insuffisance rénale aiguë par glomérulonéphrite infectieuse 25, 179-183.

Chappuis, F., Sundar, S., Hailu, A., Ghalib, H., Rijal, S., Peeling, R.W., Alvar, J., Boelaert, M., 2007. Visceral leishmaniasis: what are the needs for diagnosis, treatment and control? Nat. Rev. Microbiol. 5, S7-S16. doi:10.1038/nrmicro1748

Cruz, I., Chicharro, C., Nieto, J., Bailo, B., Cañavate, C., Figueras, M.-C., Alvar, J., 2006. Comparison of new diagnostic tools for management of pediatric Mediterranean visceral leishmaniasis. J. Clin. Microbiol. 44, 2343-7. doi:10.1128/JCM.02297-05

Desjeux, P., 1996. Leishmaniasis: Public health aspects and control. Clin. Dermatol. 14, 417-423. doi:10.1016/0738-081X(96)00057-0

Desjeux, P., 1992. Human leishmaniases: epidemiology and public health aspects. World Health Stat. Q. 45, 267-75.

du Breuil, R.M., Patel, J.M., Mendelow, B. V, 1993. Quantitation of beta-actin-specific mRNA transcripts using xeno-competitive PCR. PCR Methods Appl. 3, 57-9. 
Efstratiadis, G., Boura, E., Giamalis, P., Mandala, E., Leontsini, M., Tsiaousis, G., Memmos, D., 2006. Renal involvement in a patient with visceral leishmaniasis. Nephrol. Dial. Transplant. 21, 235-236. doi:10.1093/ndt/gfi157

El Tai, N.O., El Fari, M., Mauricio, I., Miles, M.A., Oskam, L., El Safi, S.H., Presber, W.H., Schönian, G., 2001. Leishmania donovani: Intraspecific Polymorphisms of Sudanese Isolates Revealed by PCR-based Analyses and DNA Sequencing. Exp. Parasitol. 97, 35-44. doi:10.1006/expr.2001.4592

Elshafie, A.I., Elghazali, G., Ronnelid, J., Venge, P., 2006. Cystatin C as a marker of immune complex-associated renal impairment in a Sudanese population with visceral leishmaniasis. Am. J. Trop. Med. Hyg. 75, 864-868. doi:10.4269/ajtmh.2006.75.864

Ferreira, E.C., Gontijo, C.M., Cruz, I., Melo, M.N., Silva, A.M., 2010. Alternative PCR protocol using a single primer set for assessing DNA quality in several tissues from a large variety of mammalian species living in areas endemic for leishmaniasis. Mem. Inst. Oswaldo Cruz 105, 895-898. doi:10.1590/S0074-02762010000700009

Ferroglio, E., Romano, A., Trisciuoglio, A., Poggi, M., Ghiggi, E., Sacchi, P., Biglino, A., 2006. Characterization of Leishmania infantum strains in blood samples from infected dogs and humans by PCR-RFLP. Trans. R. Soc. Trop. Med. Hyg. 100, 636-641. doi:10.1016/j.trstmh.2005.09.008

Fisa, R., Riera, C., López-Chejade, P., Molina, I., Gállego, M., Falcó, V., Ribera, E., Portús, M., 2008. Leishmania infantum DNA Detection in Urine from Patients with Visceral Leishmaniasis and after Treatment Control. Am. J. Trop. Med. Hyg. 78, $741-$ 744. doi:10.4269/ajtmh.2008.78.741

Fraga, T.L., Brustoloni, Y.M., Lima, R.B., Dorval, M.E.C., Oshiro, E.T., Oliveira, J., Oliveira, A.L.L. de, Pirmez, C., 2010. Polymerase chain reaction of peripheral blood as a tool for the diagnosis of visceral leishmaniasis in children. Mem. Inst. Oswaldo Cruz 105, 310-313. doi:10.1590/S0074-02762010000300011

Guerin, P.J., Olliaro, P., Sundar, S., Boelaert, M., Croft, S.L., Desjeux, P., Wasunna, M.K., Bryceson, A.D., 2002. Visceral leishmaniasis: current status of control, diagnosis, and treatment, and a proposed research and development agenda. Lancet Infect. Dis. doi:10.1016/S1473-3099(02)00347-X

Hotez, P.J., Bottazzi, M.E., Franco-Paredes, C., Ault, S.K., Periago, M.R., 2008. The 
Neglected Tropical Diseases of Latin America and the Caribbean: A Review of Disease Burden and Distribution and a Roadmap for Control and Elimination. PLoS Negl. Trop. Dis. 2, e300. doi:10.1371/journal.pntd.0000300

Khan, G., Kangro, H.O., Coates, P.J., Heath, R.B., 1991. Inhibitory effects of urine on the polymerase chain reaction for cytomegalovirus DNA. J. Clin. Pathol. 44, 360-5. doi:10.1136/JCP.44.5.360

Lachaud, L., Chabbert, E., Dubessay, P., Reynes, J., Lamothe, J., Bastien, P., 2001. Comparison of various sample preparation methods for PCR diagnosis of visceral leishmaniasis using peripheral blood. J. Clin. Microbiol. 39, 613-7. doi:10.1128/JCM.39.2.613-617.2001

Lima Junior, M.S. da C., Andreotti, R., Dorval, M.E.M.C., Oshiro, E.T., Oliveira, A.G. de, Matos, M. de F.C., 2009. Identificação de espécies de Leishmania isoladas de casos humanos em Mato Grosso do Sul por meio da reação em cadeia da polimerase. Rev. Soc. Bras. Med. Trop. 42, 303-308. doi:10.1590/S0037-86822009000300012

Madisen, L., Hoar, D.I., Holroyd, C.D., Crisp, M., Hodes, M.E., Reynolds, J.F., 1987. The effects of storage of blood and isolated DNA on the integrity of DNA. Am. J. Med. Genet. 27, 379-390. doi:10.1002/ajmg.1320270216

Maniatis, T., Fritsch, E.F., Sambrook, J., 1982. Molecular cloning : a laboratory manual. Cold Spring Harbor Laboratory.

Mebrahtu, Y.B., Hendricks, L.D., Oster, C.N., Lawyer, P.G., Perkins, P. V., Pamba, H., Koech, D., Roberts, C.R., 1993. Leishmania donovani Parasites in the Nasal Secretions, Tonsillopharyngeal Mucosa, and Urine Centrifugates of Visceral Leishmaniasis Patients in Kenya. Am. J. Trop. Med. Hyg. 48, 530-535. doi:10.4269/ajtmh.1993.48.530

Milde, A., Haas-Rochholz, H., Kaatsch, H.-J., 1999. Improved DNA typing of human urine by adding EDTA. Int. J. Legal Med. 112, 209-210. doi:10.1007/s004140050237

Motazedian, M., Fakhar, M., Motazedian, M.H., Hatam, G., Mikaeili, F., 2008. A urinebased polymerase chain reaction method for the diagnosis of visceral leishmaniasis in immunocompetent patients. Diagn. Microbiol. Infect. Dis. 60, 151-154. doi:10.1016/j.diagmicrobio.2007.09.001

Oliveira, J.M. de, Fernandes, T.D., Oshiro, E.T., Oliveira, A.L.L. de, Alves, T.P., Dorval, 
M.E.C., Fernandes, A.C., 2010. Mortalidade por leishmaniose visceral: aspectos clínicos e laboratoriais. Rev Soc Bras Med Trop 188-193.

Prasad, L.S., Sen, S., Ganguly, S.K., 1992. Renal involvement in kala-azar. Indian J. Med. Res. 95, 43-6.

Romero Maroto, J., López López, C., Mayol, M.J., Roig, P., Gómez Ruiz, J.J., Quilez Fenoll, J.M., 1995. Renal and urinary tract leishmaniasis. A disease to keep in mind. Actas Urol. Esp. 19, 789-94.

Salgado Filho, N.S., Márcia, T., Ferreira, A.F., Costa, J.M.L., 2003. Envolvimento da função renal em pacientes com leishmaniose visceral (calazar) Involvement of the renal function in patients with visceral leishmaniasis (kala-azar). Rev. Soc. Bras. Med. Trop. 36, 217-221.

Schönian, G., Nasereddin, A., Dinse, N., Schweynoch, C., Schallig, H.D.F.., Presber, W., Jaffe, C.L., 2003. PCR diagnosis and characterization of Leishmania in local and imported clinical samples. Diagn. Microbiol. Infect. Dis. 47, 349-358. doi:10.1016/S0732-8893(03)00093-2

Silva, M.A.L. da, Medeiros, Z., Soares, C.R.P., Silva, E.D. da, Miranda-Filho, D.B., Melo, F.L. de, Silva, M.A.L. da, Medeiros, Z., Soares, C.R.P., Silva, E.D. da, Miranda-Filho, D.B., Melo, F.L. de, 2014. A comparison of four DNA extraction protocols for the analysis of urine from patients with visceral leishmaniasis. Rev. Soc. Bras. Med. Trop. 47, 193-197. doi:10.1590/0037-8682-0233-2013

Solano-Gallego, L., Rodriguez-Cortes, A., Trotta, M., Zampieron, C., Razia, L., Furlanello, T., Caldin, M., Roura, X., Alberola, J., 2007. Detection of Leishmania infantum DNA by fret-based real-time PCR in urine from dogs with natural clinical leishmaniosis, Veterinary Parasitology. doi:10.1016/j.vetpar.2007.04.013

Tohgi, H., Utsugisawa, K., Yoshimura, M., Nagane, Y., Mihara, M., 1998. Age-related changes in nicotinic acetylcholine receptor subunits $\alpha 4$ and $\beta 2$ messenger RNA expression in postmortem human frontal cortex and hippocampus. Neurosci. Lett. 245, 139-142. doi:10.1016/S0304-3940(98)00205-5

Zijlstra, E.E., Ali, M.S., El-Hassan, A.M., El-Toum, I.A., Satti, M., Ghalib, H.W., Kager, P.A., 1992. Kala-azar: a comparative study of parasitological methods and the direct agglutination test in diagnosis. Trans. R. Soc. Trop. Med. Hyg. 86, 505-507. 
doi:10.1016/0035-9203(92)90086-R 
Figure 1. PCR products; $2 \%$ gel agarose. Molecular markers (100 bp): 1-19, patients; 20 22 , positive controls; $23-25$, negative controls.

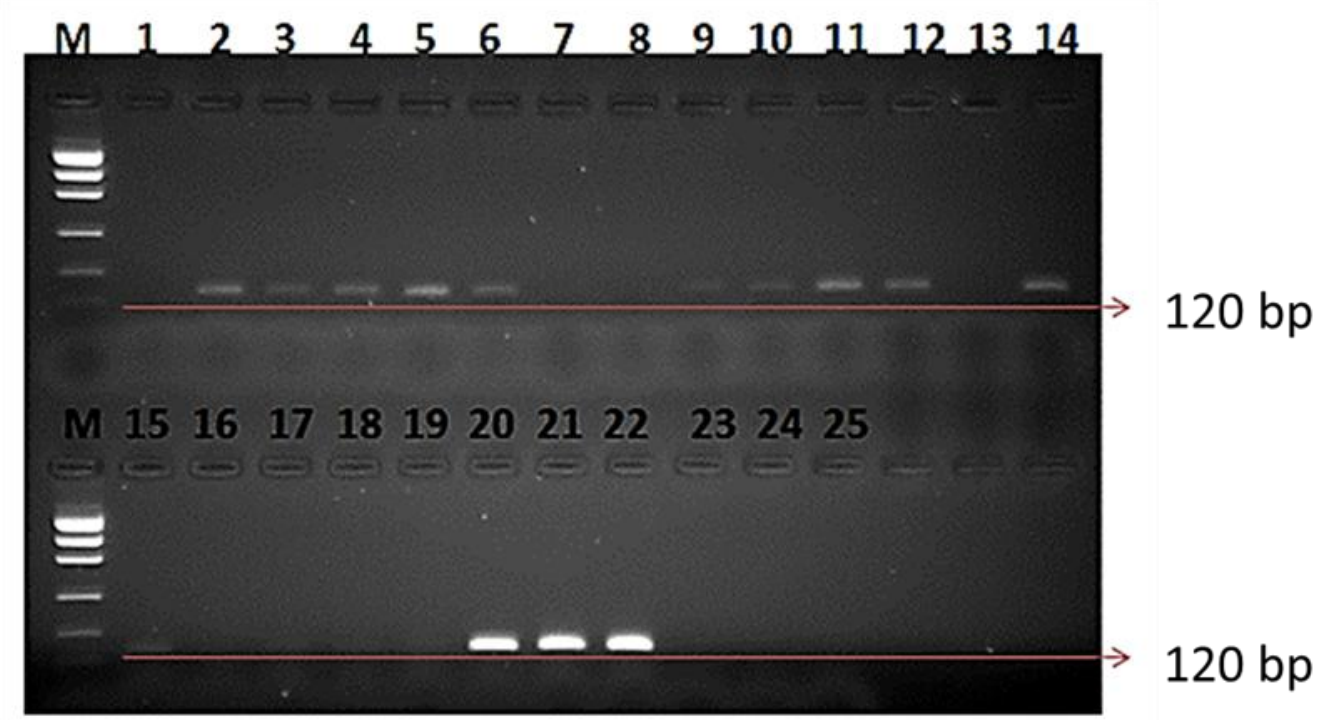

Figure 2. Product of digestion of the ITS-1 region with HAE III: (1) 50 bp ladder; (2-6) DNA from urine; (7) L. (Viannia) braziliensis; (8) L. (L.) amazonensis; (9) Leishmania (Leishmania) infantum; (10) 50 bp ladder.

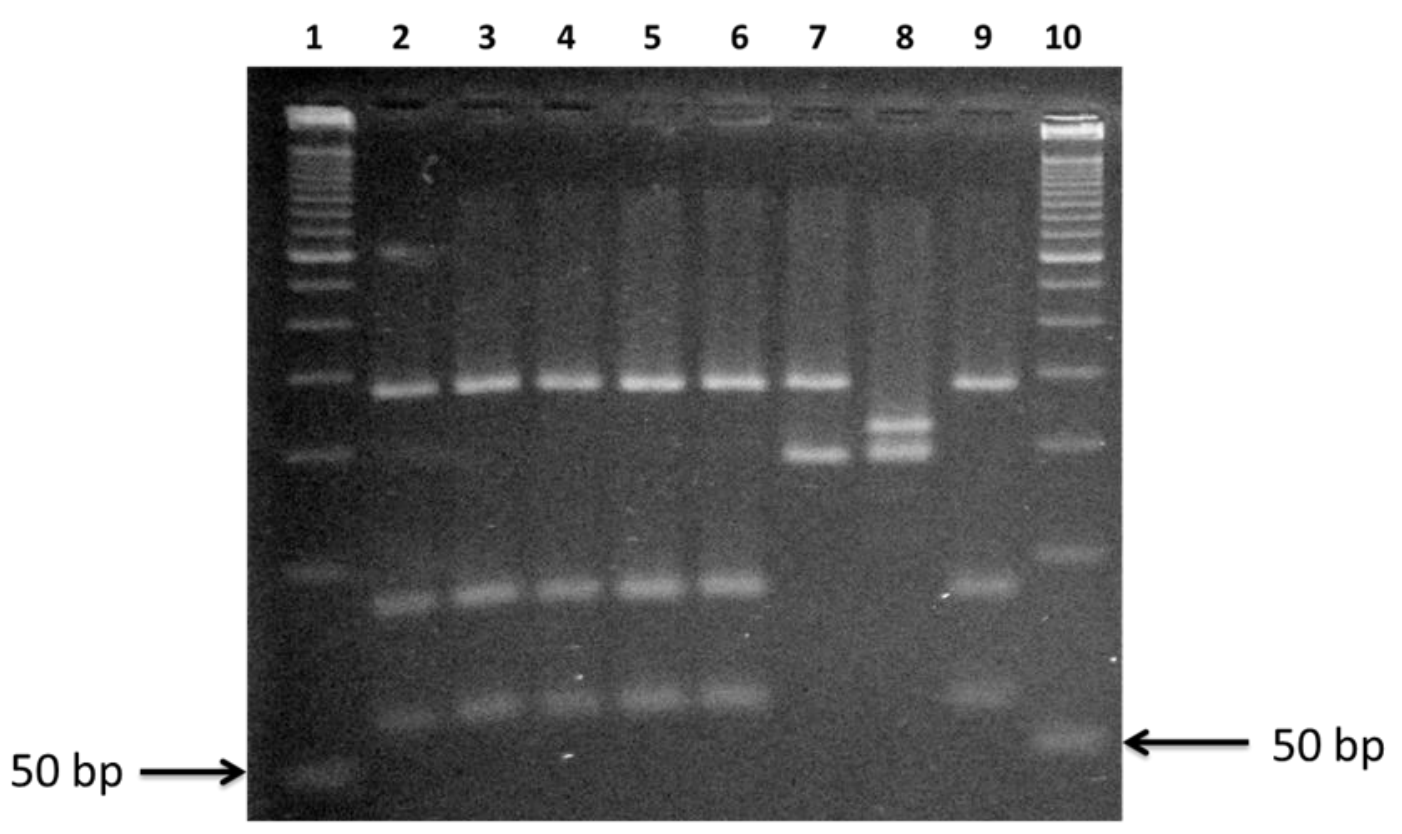

